\title{
RESUME SISTEM EKONOMI SOSIALIS
}

\author{
Oleh \\ Azizah Nur Adilah \\ 90100118048 \\ Jurusan Ekonomi Islam \\ Fakultas Ekonomi dan Bisnis Islam UIN Alauddin Makassar \\ e-mail: azizahnuradilah00@gmail.com
}

\section{A. Pengertian Sistem Ekonomi Sosialis}

Sistem ekonomi sosialis merupakan suatu bentuk yang berlawanan dari sistem ekonomi kapitalis yang dianggap menyebabkan pemerataan kesejahteraan tidak tercapai. Jika. Pemerintah mempunyai peran yang besar dalam mengatur jalannya perekonomian di sebuah negara pada sistem ekonomi sosialis, berbeda dengan sistem ekonomi kapitalis yang sepenuhnya menyerahkan siklus ekonomi pada mekanisme pasar yang berkembang. Peran yang dilakukan pemerintah pada sistem ekonomi sosialis mencakup proses perencanaan, pelaksanaan, sampai pengawasan terhadap rantai perekonomian masyarakat. ${ }^{1}$

Pada sistem ekonomi sosialis, individu tetap diberikan kebebasan dalam melakukan aktivitas ekonomi walaupun sangat terbatas sekali dan terdapat campur tangan pemerintah yang sangat besar, sehingga tidak berarti individu tidak mendapat kebebasan sama sekali. ${ }^{2}$

Sistem ekonomi sosialis memandang bahwa segala bentuk sumber kekayaan dan alat-alat produksi adalah milik bersama masyarakat. Para anggota masyarakat secara individu tidak memiliki hak kecuali pada retribusi yang mereka peroleh sebagai bentuk pelayanan absolut. Negara hadir menggantikan masyarakat dengan dominasi sebagai kekuatan tunggal. ${ }^{3}$

Carla menguraikan 5 ciri pokok dari sistem ekonomi sosialis: Pertama, Negara atas nama pemerintah memiliki dan menguasai semua sumber ekonomi. Kedua, mengusahakan bersama seluruh kegiatan ekonomi dan produksi. Ketiga, Pemerintah membentuk Badan Perencana Pusat yang menentukan jumlah dan jenis barang yang harus diproduksi. Keempat, pemerintah mengendalikan dan menentukan harga dan penyaluran barang. Kelima, semua warga negara masyarakat dianggap sebagai karyawan yang wajib ikut serta dalam proses produksi sesuai kemampuan. ${ }^{4}$

\footnotetext{
${ }^{1}$ Itang \& Adib Daenuri, "Sistem Ekonomi Kapitalis, Sosialis dan Islam”, Vol. 18 No. 1, 2017, Hal.76

${ }^{2}$ Muhammad Tho'in, "Konsep Ekonomi Islam Jalan Tengah (Kapitalis - Sosialis)", Jurnal Ilmiah Ekonomi Islam Vol. 01 NO. 03, November 2015, hal. 125

${ }^{3}$ Agus Gunawan, "Kepemilikan dalam Islam", TAZKIYA Jurnal Keislaman, Kemasyarakatan \& Kebudayaan, Vol. 18 No. 2, 2017, hal. 149

${ }^{4}$ Mohammad Ghozali, Sunan Autad Sarjana dan Achmad Arif, "Ekonomi Syariah dalam Hegemoni Faham Kapitalisme dan Sosialisme; Sebuah Solusi Pola Hidup Muslim”, Volume 13 Nomor 1, April 2019, hal. 107
} 


\section{B. Sejarah Ekonomi Sosialisme}

Karl Marx mulai mengutaran Sistem Ekonomi Sosialis dalam bukunya Das Kapital yang menyampaikan sebuah kritik terhadap Sistem Ekonomi Kapitalis yang dianggap gagal mewujudkan sebuah kestabilan sistem ekonomi. Selain Karl Marx tokoh lain yang juga seangkatan ialah Friderich Engels. Intervensi pusat adalah Ide asal yang dianut oleh Sistem Sosialis dimana pusat (centralized management) mendistribusikan harta yang dianggap sebagai milik bersama. Menjelang tahun 1930-an Sistem Sosialis mengaarah ke Sosialis Pasar yang mulai mempertimbangkan peran individu dan pasar sehingga Intervensi pusat mulai berkurang (decentralized management) karena dianggap bahwa penyertaan pasar sebagai suatu sistem sosialis terencana. Dalam hal ini, proses pendistribusian pendapatan menganggap perancang sebagai unsur yang paling penting (Gregory \& Stuart, 1995:72). ${ }^{5}$

Sejak pertengahan abad $19 \mathrm{M}$, transformasi pada ekonomi dan kemasyarakatan adalah dua hal yang ditimbulkan oleh sistem kapitalis yang dianggap sebagai faktor pendorong pesatnya pertumbuhan kapitalis produksi

a. Dari pandangan ekonomi, kekayaan dan kemakmuran diharapkan dapat bertambah dari sistem kapitalis. Padahal kenyataannya setiap tujuh atau sepuluh malah terjadi krisis produksi yang berlebihan secara absolute sehingga pasar menjadi stagnan dan tidak dinamis, harga komoditas merosot sehingga mengakibatkan kebangkrutan dan maraknya kejahatan diantara pekerja.

b. Dari pandangan kemasyarakatan, kelas pemilik modal dan kelas buruh menjadi dua kelompok masyarakat yang paling bertentangan yang berusaha saling menjatuhkan. Di satu sisi mereka bergabung dalam organisasi pertahanan dan asosiasi pemilik modal namun juga tergabung serikat buruh di sisi lainnya. Banyaknya kejahatan dan kezaliman yang timbul akibat beratnya tugas buruh yang dibebankan oleh pemilik modal dan ketidaksesuaian upah yang dituntut oleh para pekerja. ${ }^{6}$

\section{Ciri-ciri dan Prinsip Ekonomi Sosialisme}

Beberapa ciri sistem ekonomi sosialis:

a. Kebersamaan atau kolektivitas lebih diutamakan.

b. Peran yang sangat besar dimiliki oleh pemerintah

c. Pola produksi menentukan sifat manusia

d. Tidak diakuinya hak milik individu

\footnotetext{
${ }^{5}$ Boy Syamsul Bakhri, "Sistem Ekonomi Islam dalam Perbandingan”, Jurnal Al-hikmah Vol. 8, No. 1, April 2011, hal. 44

${ }^{6}$ Agus Gunawan, “Kepemilikan dalam Islam”, TAZKIYA Jurnal Keislaman, Kemasyarakatan \& Kebudayaan, Vol. 18 No. 2, 2017, hal. 149-150
} 
Prinsip dasar sistem ekonomi sosialis menurut Caporaso (2008), adalah sebagai berikut:

a. Pemerintah menguasai harta secara keseluruhan. Individu tidak memilik hak untuk memiliki harta atau memanfaatkan produksi. Seluruh bentuk produksi dan sumber pendapatan menjadi milik masyarakat secara keseluruhan.

b. Kesamaan ekonomi. Sistem ekonomi sosialis menyatakan, (walaupun sulit ditemui disemua negara komunis) bahwa prinsip kesamaan menentukan hak-hak individu dalam suatu bidang ekonomi. Kebutuhan hidup disediakan bagi tiap individu berdasarkan keperluan masing-masing.

c. Semua aturan produksi dan distribusi terkait buruh diambil alih oleh negara. ${ }^{7}$

\section{Kelebihan dan Kekurangan Ekonomi Sosialisme}

Kelebihan sistem ekonomi sosialis:

a. Pemerintah mengendalikan semua kegiatan ekonomi agar mudah melakukan kontrol atau pengawasan.

b. Anggota Masyarakat tidak memiliki kesenjangan ekonomi yang mencolok.

c. Pembentukan harga pasar atas barang dan jasa mudah diatur oleh pemerintah.

Kekurangan sistem ekonomi sosialis:

a. Dapat melemahkan dan mematikan inisiatif serta kreativitas individu.

b. Menjadi praktik monopoli yang membuat masyarakat rugi.

c. Tidak adanya kebebasan masyarakat dalam memiliki sumber-sumber daya yang ada. ${ }^{8}$

\section{DAFTAR PUSTAKA}

Itang \& Adib Daenuri. “Sistem Ekonomi Kapitalis, Sosialis dan Islam”. Vol. 18 No. 1, 2017

Tho'in, Muhammad. "Konsep Ekonomi Islam Jalan Tengah (Kapitalis - Sosialis)". Jurnal Ilmiah Ekonomi Islam Vol. 01 NO. 03, November 2015

Gunawan, Agus. "Kepemilikan dalam Islam". TAZKIYA Jurnal Keislaman, Kemasyarakatan \& Kebudayaan. Vol. 18 No. 2, 2017

Ghozali, Mohammad, Sunan Autad Sarjana dan Achmad Arif. "Ekonomi Syariah dalam Hegemoni Faham Kapitalisme dan Sosialisme; Sebuah Solusi Pola Hidup Muslim". Volume 13 Nomor 1, April 2019

Bakhri, Boy Syamsul. "Sistem Ekonomi Islam dalam Perbandingan". Jurnal Al-hikmah Vol. 8, No. 1, April 2011

\footnotetext{
${ }^{7}$ Muhammad Tho'in, “Konsep Ekonomi Islam Jalan Tengah (Kapitalis - Sosialis)”, Jurnal Ilmiah Ekonomi Islam Vol. 01 NO. 03, November 2015, hal. 125

${ }^{8}$ Muhammad Tho'in, "Konsep Ekonomi Islam Jalan Tengah (Kapitalis - Sosialis)”, Jurnal Ilmiah Ekonomi Islam Vol. 01 NO. 03, November 2015, hal. 126
} 